\title{
IMPACTS OF ORGANIC AND INORGANIC FERTILIZERS ON GROWTH AND YIELD OF COUNTRY BEAN (LABLAB PURPUREUS L.) IN SUMMER SEASON
}

\author{
Md. Sazzat Hossain Raihan \\ Department of Agriculture \\ Noakhali Science and Technology University, Noakhali-3814, Bangladesh \\ E-mail: sazzatraihan@gmail.com \\ Mohammad Shafiqul Islam \\ Assistant Professor \\ Department of Agriculture \\ Noakhali Science and Technology University, Noakhali-3814, Bangladesh \\ E-mail: safi.agri21@gmail.com \\ Md. Morshedul Islam \\ MS Student \\ Department of Plant Pathology \\ Faculty of Agriculture \\ Bangladesh Agricultural University, Mymensingh-2202, Bangladesh \\ E-mail: morshedkhan2103@gmail.com \\ Rafat Nur Abdullah Khan \\ MS Student \\ Department of Soil Science \\ Faculty of Agriculture \\ Bangladesh Agricultural University, Mymensingh-2202, Bangladesh \\ E-mail: rafatn9610@gmail.com \\ Belayet Hossain \\ MS Student \\ Department of Horticulture \\ Faculty of Agriculture \\ Bangladesh Agricultural University, Mymensingh-2202, Bangladesh \\ E-mail: belayet50718@bau.edu.bd
}

\begin{abstract}
A field experiment was conducted from April to September in 2018 at Nobogram Agro farm, Noakhali, Bangladesh. The experiment was done to determine the effect of organic and inorganic fertilizers on growth and yield of country bean (Lablab purpureus L.) in Summer Season. The experiment comprises on country bean local variety named 'Epsha-2'. There were
\end{abstract}


four treatments viz., T1= Control (no fertilizer are used), T2= Inorganic $(T S P 0.50 \mathrm{gm} /$ pit + Gypsum $200 \mathrm{gm} /$ pit + MOP $250 \mathrm{gm} / \mathrm{pit}), T 3=$ Cowdung $(5 \mathrm{~kg} / \mathrm{pit})$ and T4=FYM (5 kg/pit) and the experiment was laid out in Randomized Complete Block Design (RCBD) with six replications. The parameters of the experiment were the percentage of seed germination, plant height at four-leaf stage (cm), days to first flowering (days), number of pod per plant, individual pod length $(\mathrm{cm})$, pod width $(\mathrm{cm})$ and pod weight $(\mathrm{gm})$.Among all treatments farmyard manure (FYM) was responsible for a higher percentage of seed germination (100\%), maximum plant height during four-leaf stage $(6.08 \mathrm{~cm})$, accelerated days to first flowering (48 days), increased pod number per plant (220.33), the maximum number of individual pod length $(6.87 \mathrm{~cm})$, pod width $(2.07 \mathrm{~cm})$ and pod weight $(5.53 \mathrm{gm})$ over other treatments in summer country bean. So the results showed that farmyard manure strongly influenced plant growth and yield component of the country bean. In brief, application of FYM is necessary to increase country bean production in summer season.

Keywords: Country Bean, Growth, Inorganic Fertilizer, Organic Fertilizer, Yield.

\section{INTRODUCTION}

Country bean botanically known as Lablab purpureus L.which is a legume species. It is a selfpollinated crop belonging to the family Fabaceae. It is the third most important vegetable in the central and south-western parts of Bangladesh after eggplant and taro (Rashid, Rahman, Shahadad Hussain, \& Motiur Rahaman, 2007). In Bangladesh, it is popularly known as 'Seem'. It also has many synonyms like Dolichos bean, hyacinth bean, lablab bean, Indian bean, common bean, field bean etc. (Heuzé et al., 2016). Country bean is originated in India, and it is grown throughout the tropical regions of Asia, Africa and America (Preetham, Kumar, Srinivas, Rao, \& Prakash (2019). The crop is commonly used for pulse, vegetable and fodder. It is generally grown for pods as edible vegetable and dry seeds as a pulse which is rich in protein, fibre, vitamins and minerals (Asaduzzaman, Bhuiyan, Hossain, \& Raffi, 2015). The foliage of the crop also used as silage and green manure (Preetham, Kumar, Srinivas, Rao, \& Ramprakash, 2020). It occupies a unique position as vegetable among the legume crops due to its high nutritive value (Basu, Samantha, \& Sasmala, 2002).Total land area under country bean cultivation is 50888 acres, and the production is 134860 metric tons during 2017-18 (Bangladesh Bureau of Statistics, 2018). Though country bean can be produced all over Bangladesh, the districts Chittagong, Comilla, Noakhali and Dhaka were the intensive bean producing areas (Sharmin, Mitra, \& Rashid, 2018). In Bangladesh, the production of vegetable is not uniform around the year, much in winter season but less in summer season. Around 30\% of total vegetables are produced during summer and $70 \%$ in winter (Hossain, 1992). Therefore there is a big gap between winter and summer vegetable production in Bangladesh. Country bean is mostly grown in winter season, but due to its photo and thermo sensitive behaviour, availability of country bean is restricted during the winter season (Roy, Islam, \& Debnath, 2014). To minimize this problem Olericulture division of Bangladesh Agricultural Research Institute have been successfully developed some photo and thermo insensitive country bean through genetic manipulation which are suitable for the summer season (Anonymous, 2011).But pod bearing potentiality of those varieties is very poor because the poor holding of flower during the offseason. Such a pitiable fruit setting might be due to lack of sufficient amounts of nutrients. The requirements of fertilizers in the bean are essential for the growth and total production of pod yield. Over the years, inorganic fertilizers have been widely used worldwide to support and optimize the development of these vegetables. 
But nowadays, the use of organic fertilizer has gained more importance globally in the last few decades (Islam, Boyce, Rahman, Azirun, \& Ashraf, 2016).Application of these organic and inorganic compounds have been shown to improve the soil nutritional status and as well as to influence other soil properties (Pagliai, Vignozzi, \& Pellegrini, 2004), which helps to maintain the quality and yield component of crops. So, the production of these legume vegetables sufficient amount of nutrients are needed for their growth and development (Takahashi, 1981) otherwise pod growth habit, pod quality, pod yield etc. can be affected. Therefore, this research investigated to find out the response of country bean to organic and inorganic fertilization and to identify the possible fertilizer treatment which enhances country bean production during the summer season.

\section{Experimental Site}

\section{MATERIALS AND METHODS}

The experiment was conducted during the period from April to September in 2018 at Nabogram Agro Farm near the Manannogor, Sadar Upazila, Noakhali District, Bangladesh. Location of the site is $24^{\circ} 75^{\prime} \mathrm{N}$ latitude and $90^{\circ} 5^{\prime} \mathrm{E}$ longitude which falls under the AEZ 18, i.e. Young Meghna Estuarine Flood plain. The climate of the experimental site was tropical. The soil was sandy loam in texture and slightly saline soil which $\mathrm{pH}$ was 7.5-8.3.

\section{Experimental Design and Treatments}

In this experiment 'Epsha-2' variety was used and the experiment was laid out in Randomized Complete Block Design (RCBD) with four treatments and six replications. Four treatments were considered: T1= Control (no fertilizer are used), T2= Inorganic (TSP $0.50 \mathrm{gm} / \mathrm{pit}+$ Gypsum 200 gm/pit + MOP $250 \mathrm{gm} / \mathrm{pit}), \mathrm{T} 3=$ Cowdung (5 kg/pit) and T4= FYM (5 kg/pit).

\section{Land Preparation}

The land was well ploughed at tilth condition. Cowdung, FYM and all fertilizers except urea, were applied during final land preparation according to treatment. Seed sowing was done on April 04 in 2018, in the plot. The size of each plot was $4.5 \mathrm{~m}$ length and $1 \mathrm{~m}$ width, height was $0.05 \mathrm{~m}$, in every plot six pits was prepared, and each hole was $0.25 \mathrm{~m}^{2}$. By following process 24 plot were prepared separately. Before sowing, seed treatment was done with Furadan @ 5gm. The seeds pushed into the ground to a depth of approximately 1 to 1.5 inches. Three bean seeds placed 3 inches apart at each pit. Intercultural operations were appropriately done when required. Harvesting was done regularly and from time to time.

\section{Data collection}

One plant from each pit was selected and tagged. Thus was done in all the six replications and the different data were recorded from those plants. Data on the following parameters were recorded from the experimental plot. The number of seeds sown per pit and their germination was recorded in $\%$ at ten days after sowing. Height of plant was recorded in centimetre $(\mathrm{cm})$ at four-leaf stage. The number of days from sowing to first flower opening was recorded as days to first flowering (days). The number of the pods was counted during harvest time. Pods from the tagged plant harvested and individual length were calculated in centimetre $(\mathrm{cm})$. Individual pods widths were calculated in centimetre $(\mathrm{cm})$.Harvested pods weight were calculated in grams $(\mathrm{gm})$. 


\section{Data analysis}

Data were analyzed using SPSS statistical software and Microsoft Office Excel 2013 to find out the significance of the difference among the treatments. The analysis was performed by F-test. Least Significant Different (LSD) values at 5\% level of probability were used to determine the significance of the difference between treatment means.

\section{RESULT AND DISCUSSION}

\section{Percentage of seed germination}

Regarding seed germination at 10 DAS variation was found among the practised treatments (Figure 1).In T4 (FYM) treatment, the percentage of seed emergence is maximum (100\%) and the lowest percentage of seed emergence observed in T1 (Control) treatment. On the contrary, inorganic and cowdung showed less rate of seed emergences than FYM. Gupta, Narwa, and Antil (1996) said that FYM contains all the macro and micronutrients required for plant growth as well as seed emergences. Chinthapalli, Dibar, Chitra, and Leta (2015) observed that organic fertilizer showed a high frequency of $92-96 \%$ germination when compared with inorganic fertilizer of $80-86 \%$ germination over the control in fava bean and pea. Hence, FYM maintains organic matter in soil and improving nutrient and structural status of soils which influence the percentage of bean seed germination.

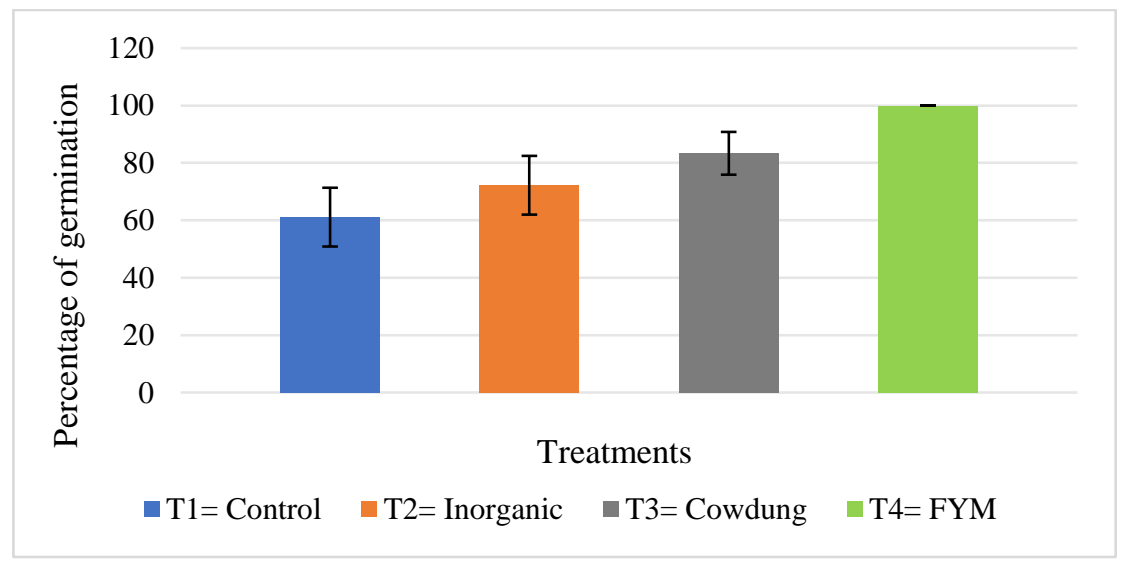

Figure 1. Effect of organic and inorganic fertilizers on seed germination of country bean at 10 DAS. The vertical bar indicates LSD at 5\% level of significance. (DAS= Days after sowing, FYM= Farmyard manure)

\section{Plant height (cm)}

It is evident from figure 2 that, the different treatments exhibited a significant effect on plant height at four-leaf stage. The maximum plant height was found from T4 $(6.08 \mathrm{~cm})$ at four-leaf stage. On the other hand, the minimum plant height was found from T1 $(4.33 \mathrm{~cm})$ at four-leaf stage. Yeshiwas, Zewdie, Chekol, and Walle (2018) showed that highest plant height was obtained from the application of nitrogen fertilizer combined with farmyard manure, respectively lowest plant height was obtained from no application of farmyard manure. From this result, it 
can be inferred that, farmyard manure showed a remarkable change in country bean plant height at four-leaf stage compared to the other treatments.

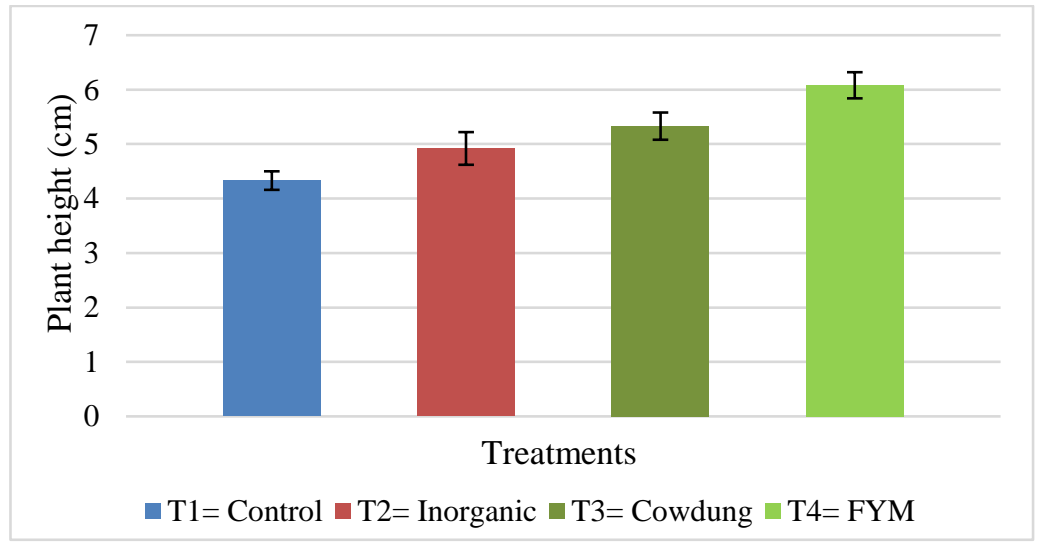

Figure 2. Effect of organic and inorganic fertilizers on plant height of country bean. The vertical bar indicates LSD at 5\% level of significance. (FYM= Farmyard manure)

\section{Days to first flowering (days)}

Considering the first flowering date, significant variations were noticed among all treatments, (Figure 3).In T2treatment the maximum days for flowering was found (58.67 days) and the minimum days for flowering was found in T4 treatment (48 days). Purseglove (1977) reported that some of the hyacinth bean varieties produced flowers at about six weeks after sowing.Hence, FYM accelerates days to first flowering over other treatments in summer bean. Barua, Rahman, Patwary, Alam, and Nahar (2014) found that 38 days were needed for flower bud emergence in his study.

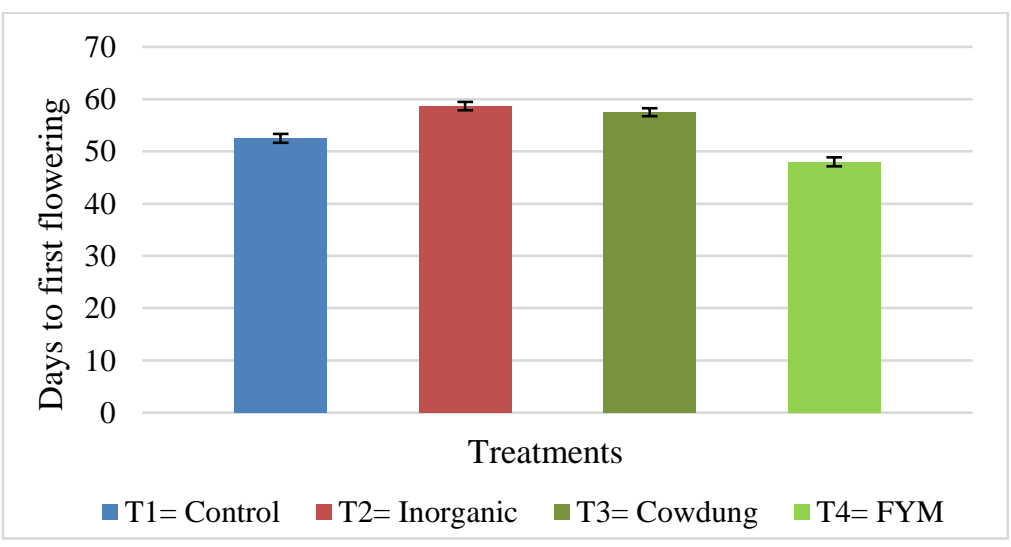

Figure 3. Effect of organic and inorganic fertilizers on days to the first flowering of the country bean. The vertical bar indicates LSD at $5 \%$ level of significance. (FYM= Farmyard manure)

\section{Number of pods per plant}

This study revealed that statistically significant differences existed among all treatments for average number of pods per plant (Figure 4).Data showed the highest pods number per plant (220.33) was observed from T4 (FYM) treatment, while the lowest (127.83) related to T1(Control) treatment. Amount of T2 (177.33) and T3 (144.33) consider as medium pods number per plant. Singh, Sekhon, and Kaur (2012) reported that application of 5 tons FYM ha-1 
improved the plant growth and yield attributes either numerically or significantly and increased grain yield significantly over no application of FYM.

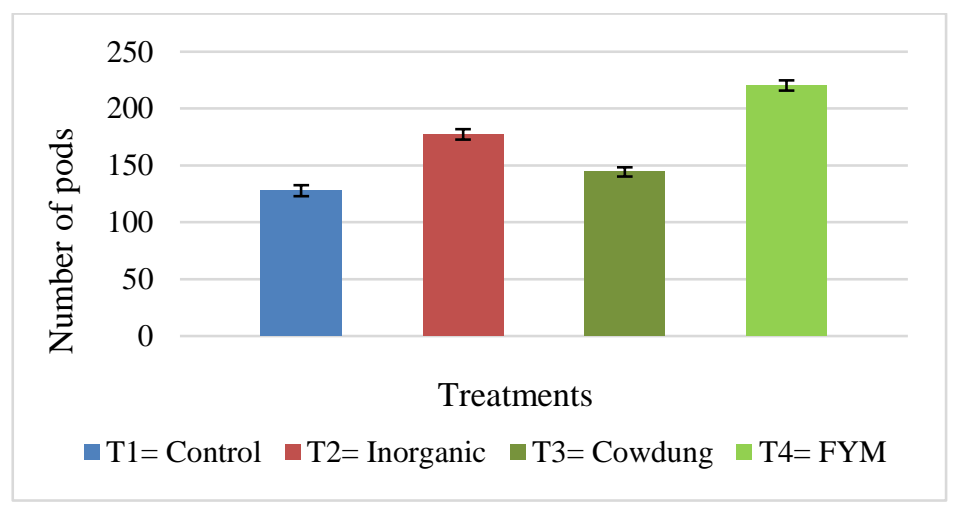

Figure 4. Effect of organic and inorganic fertilizers on the number of pods per plant. The vertical bar indicates LSD at 5\% level of significance. (FYM= Farmyard manure)

\section{Individual pod length $(\mathrm{cm})$}

In respect of individual pod length, variation was found among the practised treatments (Figure 5). The maximum length of the pod was found from T4 $(\mathrm{FYM})$ treatment $(6.87 \mathrm{~cm})$ then another treatment and in T1 (Control) treatment the length of pod is minimum $(6.39 \mathrm{~cm})$. Medium pod length was found from T2 $(6.62 \mathrm{~cm})$ and T3 $(6.52 \mathrm{~cm})$. Therefore, yield and yield contributing characters of the country bean were significantly influenced by FYM and showed the maximum value, whereas the other treatments showed the lowest value.

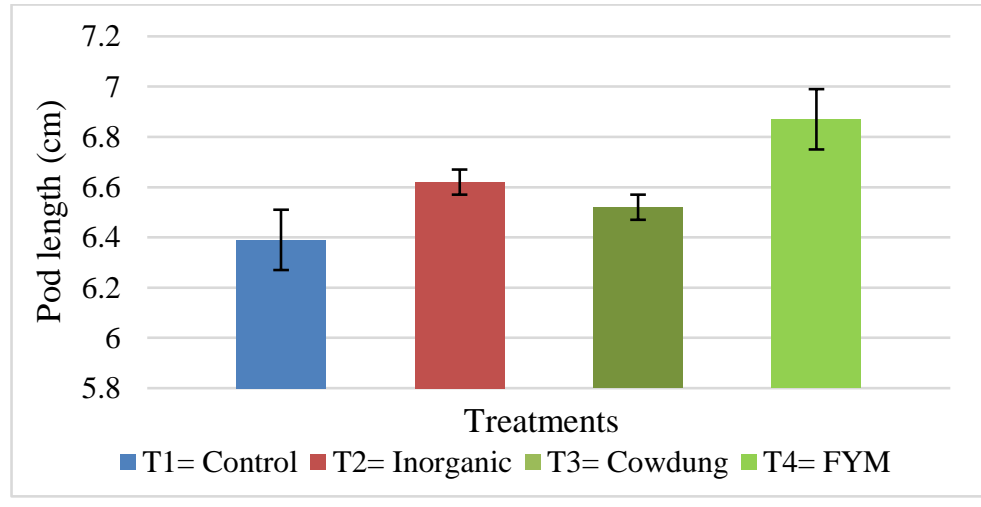

Figure 5. Effect of organic and inorganic fertilizers on individual pod length. The vertical bar indicates LSD at 5\% level of significance. (FYM= Farmyard manure)

\section{Individual pod width $(\mathbf{c m})$}

The application of organic and inorganic fertilizers significantly affected the individual pod width of country bean (Figure 6). The highest individual pod width $(2.07 \mathrm{~cm})$ was obtained from the application of T4 (FYM) treatment, while the lowest pod width $(1.80 \mathrm{~cm})$ was found from the control treatment. Singh et al. (2012) reported that application of 5 tons FYM ha ${ }^{-1}$ improved the plant growth and yield attributes either numerically or significantly and increased grain yield significantly over no application of FYM. Thus it can be inferred from this result that, the positive response of country bean to farmyard manure application could be due to the reduction of soil $\mathrm{pH}$ by the manure that makes the nutrient such as phosphorus more available to the plants. 


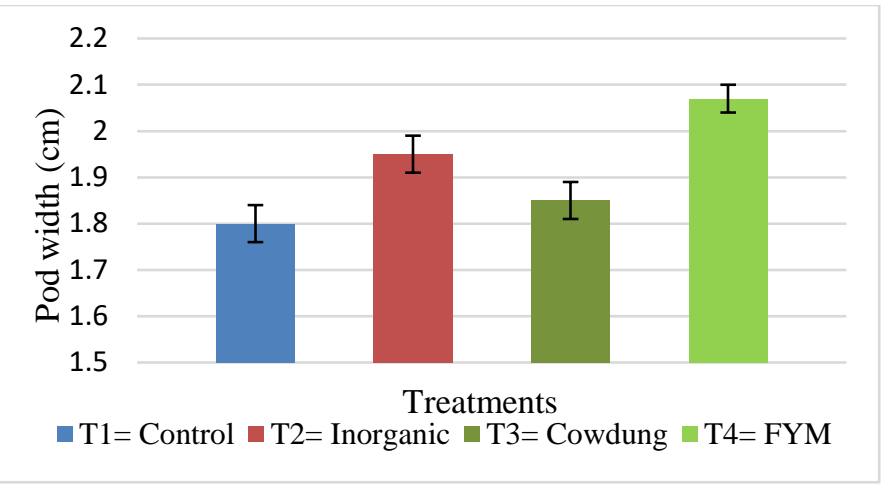

Figure 6. Effect of organic and inorganic fertilizers on individual pod width. The vertical bar indicates LSD at $5 \%$ level of significance. (FYM= Farmyard manure)

\section{Individual pod weight (gm)}

Individual pod weight of country bean was varied significantly among the different treatments of organic and inorganic fertilizers (Figure 7). The individual pod weight was recorded maximum (5.53 gm) where T4 (FYM) treatment was done, and the minimum pod weight was recorded (4.69 gm) where T1 (Control) treatment was done. So, it can be said that using of farmyard manure increased yield and yield component of the country bean. This might be due to the release of more nutrients from farmyard manure.

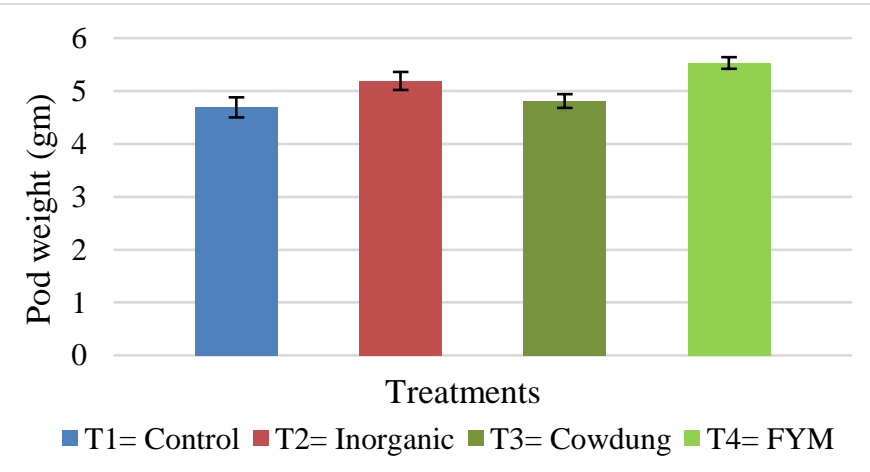

Figure 7. Effect of organic and inorganic fertilizers on individual pod weight. The vertical bar indicates LSD at 5\% level of significance. (FYM= Farmyard manure)

\section{CONCLUSION}

Singly organic and inorganic fertilizers can perform a better yield and optimum growth of legume plant species. But especially organic fertilizer can help in better plant growth and pod yield of the country bean. Soil fertility is usually maintained by the application of organic fertilizers. It also improves the physical and biological properties of the soil. According to our findings, it can be said that organic fertilizer such as farmyard manure has a significant effect on country bean production. It improves nutrient and structural status of soils which influences the seed emergence, plant growth and yield parameters of country bean in summer season. The present study results showed that farmyard manure performed the best for country bean production. Hence, farmyard manure is recommended because of its easy availability, eco friendly, and cost-effectiveness and further study should be continued in different seasons and agro-ecological zones of Bangladesh for better production. 


\section{ACKNOWLEDGMENT}

We want to thank the Department of Upazila Agricultural Extension, Sadar Upazila, Noakhali, Bangladesh for providing country bean seeds; Nobogram Agro farm, Mannannogor, Sadar Upazila, Noakhali District, Bangladesh and thank our family for their financial support towards the successful completion of this study and also thank the other teachers and students of the Departments of Agriculture, Noakhali Science and Technology University, Noakhali, Bangladesh.

\section{REFERENCES}

Anonymous. (2011). Annual Research Report 2010-2011. HRC, BARI, Gazipur, 120.

Asaduzzaman, M., Bhuiyan, M. J. H., Hossain, M. A., \& Raffi, S. A., (2015). Genetic variability, heritability and genetic advance of yield and yield contributing characters of lablab bean (Lablab purpureus L.). Progressive Agriculture, 26(1), 22-25. https://doi.org/10.3329/pa.v26i1.24510

Barua, H., Rahman, M. H., Patwary, M. A., Alam, M. Z., \& Nahar, S. (2014). Variations in growth and yield of indigenous hyacinth bean (Lablab purpureus (L.) sweet) genotypes. The Agriculturists, 12(2), 01-05.https://doi.org/10.3329/agric.v12i2.21724

Basu, A. K., Samantha, S. K., \& Sasmala, A. C. (2002). Genetic analysis for some seed parameters in Lablab bean.Vegetable Science 32(2), 129-132.

Bangladesh Bureau of Statistics. (2018). Yearbook of Agricultural Statistics of Bangladesh, Bangladesh. Bureau of Statistics, Statistical Division, Ministry of Planning, Government of the People's Republic of Bangladesh, Dhaka.

Chinthapalli, B., Dibar, D. T., Chitra, D. V., \& Leta, M. B. (2015). A comparative study on the effect of organic and inorganic fertilizers on agronomic performance of faba bean (Vicia faba L.) and pea (Pisum sativum L.). Agriculture, Forestry and Fisheries, 4(6), 263-268. https://doi.org/10.11648/j.aff.20150406.15

Gupta, A. P., Narwa, R. P., \& Antil, R. S. (1996). Effect of Farm Yard Manure and Fertilizer Nitrogen in Pearl millet-Wheat cropping Sequence. In Evaluation of Soil Organic Matter Models, 345-350. Springer, Berlin, Heidelberg.https://doi.org/10.1007/978-3-642-610943_31

Heuzé, V., Tran, G., Sauvant, D., Renaudeau, D., Bastianelli, D., \& Lebas, F. (2016). Lablab (Lablab purpureus). Feedipedia, a programme by INRA, CIRAD, AFZ and FAO, 11, 25. Retrieved from https://www.feedipedia.org/node/297

Hossain, S. M. (1992). Status, constraints and strategies of vegetable research. In Vegetable production and marketing. Proceedings of a national review and planning Workshop held at BARI, Gazipur, Bangladesh, 26-29.

Islam, M. A., Boyce, A. N., Rahman, M. M., Azirun, M. S., \& Ashraf, M. A. (2016). Effects of organic fertilizers on the growth and yield of bush bean, winged bean and yard long bean. Brazilian Archives of Biology and Technology, 59, 1-9. https://doi.org/10.1590/16784324-2016160586 
Pagliai, M., Vignozzi, N., \& Pellegrini, S. (2004). Soil structure and the effect of management practices. Soil and Tillage Research, 79(2), 131-143.

Preetham, R., Kumar, K., Srinivas, A., Rao, A. M., \& Ramprakash, T. (2020). Nutrient management on the water productivity and profitability of hyacinth bean in baby corn (Zea mays L.)-hyacinth bean (Lablab purpureus var. typicus) cropping system. International Journal of Bio-resource and Stress Management, 11(3), 225-231. https://doi.org//10.23910/1.2020.2095

Preetham, R., Kumar, K., Srinivas, A., Rao, A. M., \& Prakash,T. R. (2019). Effect of integrated nutrient management practices on growth, yield attributes and yield of hyacinth bean in baby corn (Zea mays L.)-hyacinth bean (Lablab purpureus var typicus) cropping system. Indian Journal of Agricultural Research, 53(6), 681-686. https://doi.org/10.18805/IJARe.A-5205

Purseglove, J. W. (1977). Tropical Crops. Dicotyledons. Longman, London. 273-276.

Rashid, M. A., Rahman, M. T., Shahadad Hussain, M., \& Motiur Rahaman, M. (2007). INDIGENOUS VEGETABLES IN BANGLADESH. Acta Hortic. 752, 397-400. https://doi.org/10.17660/ActaHortic.2007.752.70

Roy, K. K., Islam, M. S., \& Debnath, B. (2014). Pod Growth Behavior and Seed Production Potentiality of Photo-Insensitive Hyacinth Bean [Lablab purpureus(L.) Sweet] Genotypes.Bangladesh J. Agriculturist. 7(1), 19-22.

Sharmin, S., Mitra, S. \& Rashid, M.H.A. (2018). Production, yield and area growth of major winter vegetables of Bangladesh. Journal of Bangladesh Agricultural University, 16(3), 492-502. https://doi.org/10.3329/jbau.v16i3.39447

Singh, G., Sekhon, H. S., \& Kaur, H. (2012). Effect of Farmyard Manure, Vermicompost and Chemical Nutrients on Growth and Yield of Chickpea (Cicer arietinum L.). International Journal of Agricultural Research, 7 (2), 93-99. https://doi.org/10.3923/ijar.2012.93.99

Takahashi, K. (1981). Physiological disorders in Chinese cabbage. 225-233. N.S. Talekar and T.D. Griggs (eds.). Chinese cabbage. AVRDC, Shan Hua, Taiwan.

Yeshiwas, Y., Zewdie, B. Y. B., Chekol, A., \& Walle, A. (2018). Effect of nitrogen fertilizer and farmyard manure on growth and yield of lettuce (Lactuca sativa L.). International Journal of Agricultural Research, 13, 74-79. https://doi.org/10.3923/ijar.2018.74.79

\section{Copyrights}

Copyright for this article is retained by the author(s), with first publication rights granted to the journal. This is an open-access article distributed under the terms and conditions of the Creative Commons Attribution license (http://creativecommons.org/licenses/by/4.0/) 